\title{
Peningkatan Pertumbuhan dan Produksi Bawang Putih (Allium sativum L.) melalui aplikasi Vernalisasi dan Pemberian BAP (Benzil Amino Purin)
}

\author{
(Increased of Growth and Production of Garlic (Allium sativum L.) through Vernalization \\ and BAP (Benzyl Amino Purine) application)
}

\author{
Edi Siswadi ${ }^{1}$, Sekar Utama Putri ${ }^{1}$, Refa Firgiyanto ${ }^{1 *}$ dan Clara Fajarsyah Putri ${ }^{1}$ \\ Program Studi Produksi Tanaman Hortikultura, Departemen Produksi Pertanian, Politeknik Negeri Jember \\ J1. Mastrip, Jember 68101, Indonesia \\ *Email Korespondensi: refa_firgiyanto@polije.ac.id \\ Diterima 18 Juni 2019 /Disetujui 08 juli 2019
}

\begin{abstract}
Garlic (Allium sativum L.) is one of the horticultural plants used in daily life for various uses. This study aims to determine the effect of vernalization and concentration of BAP (Benzyl Amino Purine) and its interaction with the growth and production of garlic (Allium sativum L.) var. Lumbu Hijau. The study was carried out at the Jember State Polytechnic Plant Laboratory and land in Wonokerto Village, Sukapura District, Probolinggo District with an altitude of $1400 \mathrm{~m}$ above sea level. The experimental design used was Factorial Randomized Block Design. The first factor is five levels of vernalization (0, 2, 4, 6, and 8 weeks), while the second factor is five levels of concentration (0,50,100,150 and $200 \mathrm{ppm})$. The variables observed in this experiment included the number of leaves, leaf length, leaf width, plant height, stem diameter, tuber diameter, number of cloves, wet and dry weight of tuber. The results showed that the application of the vernalization time treatment was able to increase the growth of leaf number, leaf length, leaf width, plant height, stem diameter, clove number, wet and dry weight of tubers and tuber diameter. the best long time vernalization in increasing the growth and production of garlic was obtained in the vernalization treatment 4 weeks and 8 weeks. The treatment of BAP (Benzyl Amino Purine) concentration and its interaction with the vernalization duration is still not able to increase the growth and development of garlic of the var. Lumbu Hijau.
\end{abstract}

Keywords: BAP, tuber, vernalization

\section{ABSTRAK}

Bawang putih (Allium sativum L.) merupakan salah satu tanaman hortikultura yang digunakan dalam kehidupan seharihari untuk berbagai pengunaan. Penelitian ini bertujuan untuk mengetahui lama vernalisasi dan konsentrasi BAP (Benzil Amino Purin) serta interaksinya terhadap pertumbuhan dan produksi bawang putih (Allium sativum L.) varietas Lumbu Hijau.Penelitian dilaksanakan di Laboratorium Tanaman Politeknik Negeri Jember dan Di Desa Wonokerto Kecamatan Sukapura Kabupaten Probolinggo dengan ketinggian $1400 \mathrm{~m}$ dpl. Rancangan percobaan yang digunakan yaitu Rancangan Acak Kelompok Faktorial. Faktor pertama yaitu lima taraf vernalisasi (0, 2, 4, 6, dan 8 Minggu), sedangkan faktor kedua lima taraf konsentrasi (0, 50, 100, 150 dan 200 ppm). Variabel yang diamati pada percobaan ini meliputi jumlah daun, panjang daun, lebar daun, tinggi tanaman, diameter batang, diameter umbi, jumlah siung, berat basah, dan berat kering umbi. Hasil penelitian menunjukkan Pemberian perlakuan lama vernalisasi mampu meningkatkan pertumbuhan jumlah daun, panjang daun, lebar daun, tinggi tanaman, diameter batang, jumlah siung, berat basah, berat kering, dan diameter umbi, akan tetapi belum mampu meningkatkan lebar daun 6 MST. Waktu lama vernalisasi terbaik dalam meningkatkan pertumbuhan dan produksi bawang putih diperoleh pada perlakuan 4 minggu dan 8 minggu. Pemberian perlakuan konsentrasi BAP (Benzil Amino Purin) serta interaksinya dengan lama vernalisasi masih belum mampu meningkatkan pertumbuhan dan perkembangan bawang putih varietas Lumbu Hijau.

Kata Kunci: vernalisasi, BAP, umbi 


\section{PENDAHULUAN}

Bawang putih (Allium sativum L.) merupakan salah satu tanaman hortikultura yang digunakan dalam kehidupan sehari-hari sebagai bumbu masak dan obat-obatan oleh masyarakat Indonesia. Rata-rata konsumsi bawang putih mengalami peningkatan sebesar 4,2\% tiap tahun dalam periode 2002-2017 (Kementrian Pertanian 2016). Permintaan ini diperkirakan akan terus meningkat sejalan dengan bertambahnya penduduk Indonesia, oleh karena itu komitas ini akan menjadi sumber pertumbuhan baru ekonomi dalam pembangunan pertanian. Berdasarkan data Food and Agriculture Organization disingkat FAO (2014) Indonesia merupakan negara pengimpor bawang putih terbesar di dunia. Pada tahun 2016 impor bawang putih mencapai 448.881 ton, sedangkan produksi bawang putih di Indonesia pada tahun 2016 adalah sebanyak 21.150 ton dengan luas panen 2.407 ha (Ditjen Hortikultura 2017; BPS 2017). Jumlah ini hanya mampu memenuhi $5 \%$ dari jumlah total kebutuhan bawang putih dalam negeri. Salah satu kebijakan yang dikeluarkan oleh Pemerintah dalam mempercepat perluasan area tanam, misalnya dengan adanya kewajiban bagi importir untu melakukan pengembangan penanaman sebanyak 5\% dari total volume impor.

Bahan tanam menjadi peran penting untuk menunjang keberhasilan perluasana tanam. Penggunaan umbi yang bermutu tinggi merupakan langkah awal peningkatan produksi. Kendala dalam penggunaan bahan tanam berupa umbi bibit adalah adanya masa dormansi benih yang cukup lama yaitu 2 hingga 3 bulan. Adanya masa dormansi pada umbi bawang putih tersebut akan menghambat kelancaran proses produksi serta budidaya karena bibit tidak akan dapt tumbuh sehingga berdampak pula pada waktu tanam yang hanya dapat dilakukan satu kali dalam 1 tahun (Randi 2015). Oleh karena itu, diperlukan penerapan teknologi salah satunya dengan perlakuan suhu rendah (vernalisasi). Adanya perlakuan ini diduga mampu mempercepat proses pembelahan sel yang berperan dalam mematahkan dormansi atau hambatan pertumbuhan tanaman melalui peningkatan aktivitas giberelin endogen dan auksin sehingga tanaman dapat tumbuh normal (Jain 2007; Jasmi 2013). Pematahan dormansi berdasarkan pada penelitian Wu et al. (2015), dapat dilakukan pada suhu $5^{0} \mathrm{C}$.

Upaya peningkatan pertumbuan dan perkembangan pada tanaman bawang putih juga dapat dilakukan dengan aplikasi benzil amino purun (BAP) (Rosliani et al. 2012). Salah satu golongan sitokinin yang aktif mempengaruhi proses-proses fisiologis tanaman, seperti pembelahan dan pembesaran sel, ialah benzil amino purun (BAP) (Amanullah et al. 2010). Aplikasi BAP pada umumnya banyak digunakan untuk menginduksi tunas bawang putih pada saat dibudidayakan dikultur jaringan. Pada percobaan yang dilakukan oleh Mutmainah (2016) melaporkan pemberian BAP pada Konsentrasi 2,5 ppm mampu memberikan pengaruh yang nyata pada percepatan hari munculnya tunas adventif dan peningktan jumlah tunas adventif pada bawang putih. Berdasarkan hal tersebut maka penelitian ini bertujuan untuk mempelajari pengaruh lama vernalisasi dan aplikasi BAP terhadap pertumbuhan dan perkembangan tanaman bawanag putih serta mengetahui interkasi dari kedua perlauan tersebut.

\section{BAHAN DAN METODE}

Penelitian dilaksanakan di Laboratorium Tanaman Politeknik Negeri Jember dan di Desa Wonokerto Kecamatan Sukapura Kabupaten Probolinggo dengan ketinggian 1400 m dpl. Media tanam yang digunakan campuran tanah dengan dosis pupuk kandang 20 ton/ha. Rancanga percobaan yang digunakan dalam penelitian ini adalah rancangan acak kelompok (RAK) pola faktorial dengan tiga ulangan. Faktor yang di coba terdiri dari atas lima taraf lama vernalisasi dan konsentrasi BAP. Lama vernalisasi meliputi 0 minggu, 2 minggu, 4 minggu, 6 minggu dan 8 minggu, sedangkan konsentrasi BAP meliputi 0 ppm, 50 ppm, 100 ppm, 150 ppm dan 200 ppm. Total kombinasi perlakuan dari kedua faktor adalah 25 kombinasi dengan setiap unit percobaan terdiri atas tiga tanaman sehingga total tanaman yang digunakan berjumlah 225 tanaman. Variabel yang diamati pada percobaan ini meliputi jumlah daun, panjang daun, lebar daun, tinggi tanaman dan diameter batang yang diukur menggunakan alat bantu berupa penggaris dan jangka sorong. Variabel produksi yang diukur meliputi diameter umbi, jumlah siung, berat basah, dan berat kering umbi. Data yang diperoleh dari hasil pengamatan kemudian dianalisis dengan uji $\mathrm{F}$ untuk mengetahui adanya pengaruh pada setiap faktor. Apabila terdapat perlakuan yang berpengaruh nyata atau $\mathrm{H}_{0}$ ditolak maka akan dilanjutkan dengan uji lanjut DMRT dengan tingkat kesalahan 5\%. Analisis dilakukan dengan bntuan program SPSS versi 22.

\section{HASIL DAN PEMBAHASAN}

Hasil analisis sidik ragam menunjukkan adanya pengaruh nyata dari perlakuan lama vernalisasi terhadap jumlah daun 2, 4, 6, 8 MST, panjang daun 2, 4, 6, 8, 10 MST, lebar daun 2, 4, 8 MST, tinggi tanaman 2, 4, 6, 8 MST, diameter batang 4, 6, $10 \mathrm{MST}$, jumlah siung, berat basah (gr), berat kering (gr), dan diameter umbi (mm), akan tetapi tidak berpengaruh nyata pada lebar daun 6 MST, lebar daun 10 MST, tinggi tanaman 10 MST (Tabel 1). Pemberian BAP dengan beberapa konsentrasi tidak berpengaruh nyata pada semua parameter pertumbuhan dan perkembangan bawang putih varietas Lumbu Hijau . Begitu juga pada interaksi lama vernalisasi dan konsentrasi BAP tidak memberikan pengaruh nyata terhadap semua parameter pertumbuhan dan perkembangan bawang putih varietas Lumbu Hijau (Tabel 1). 
Tabel 1. Matrik hasil analisis sidik ragam data percobaan

\begin{tabular}{lccccc}
\hline \multirow{2}{*}{ Variabel Yang Diamati } & \multicolumn{5}{c}{ Nilai Significansy } \\
\cline { 2 - 6 } & $\begin{array}{c}\text { Vernalisasi x } \\
\text { BAP }\end{array}$ & Vernalisasi & BAP & $5 \%$ & $1 \%$ \\
\hline Jumlah Daun 2 MST & 0,6 & $0^{* *}$ & 0,33 & 0,05 & 0,01 \\
Jumlah Daun 4 MST & 0,25 & $0^{* *}$ & 0,07 & 0,05 & 0,01 \\
Jumlah Daun 8 MST & 0,98 & $0^{* *}$ & 0,2 & 0,05 & 0,01 \\
Panjang Daun 2 MST (cm) & 0,54 & $0^{* *}$ & 0,6 & 0,05 & 0,01 \\
Panjang Daun 4 MST (cm) & 0,76 & $0^{* *}$ & 0,65 & 0,05 & 0,01 \\
Panjang Daun 8 MST (cm) & 0,72 & $0^{* *}$ & 0,19 & 0,05 & 0,01 \\
Lebar Daun 2 MST (cm) & 0,57 & $0^{* *}$ & 0,9 & 0,05 & 0,01 \\
Lebar Daun 4 MST (cm) & 0,78 & $0^{* *}$ & 0,33 & 0,05 & 0,01 \\
Lebar Daun 8 MST (cm) & 0,25 & $0^{* *}$ & 0,5 & 0,05 & 0,01 \\
Tinggi Tanaman 2 MST (cm) & 0,37 & $0^{* *}$ & 0,23 & 0,05 & 0,01 \\
Tinggi Tanaman 4 MST (cm) & 0,57 & $0^{* *}$ & 0,52 & 0,05 & 0,01 \\
Tinggi Tanaman 8 MST (cm) & 0,71 & $0^{* *}$ & 0,17 & 0,05 & 0,01 \\
Diameter Batang 4 MST (mm) & 0,9 & $0^{* *}$ & 0,99 & 0,05 & 0,01 \\
Diameter Batang 6 MST (mm) & 0,4 & $0^{* *}$ & 0,05 & 0,05 & 0,01 \\
Jumlah Siung & 0,25 & $0^{* *}$ & 0,39 & 0,05 & 0,01 \\
Berat Basah (gr) & 0,19 & $0^{* *}$ & 0,8 & 0,05 & 0,01 \\
Berat Kering (gr) & 0,52 & $0^{* *}$ & 0,74 & 0,05 & 0,01 \\
Diameter Umbi (mm) & 0,58 & $0^{* *}$ & 0,92 & 0,05 & 0,01 \\
\hline
\end{tabular}

\section{A. Pengaruh Lama Vernalisasi}

Hasil penelitian menunjukkan adanya peningkatan pertumbuhan dan perkembangan tanaman bawang putih varietas Lumbu Hijau setelah adanya perlakuan lama vernalisasi. Rerata jumlah daun tanaman bawang putih pada pengamatan umur 2 MST mendapati rerata tertinggi pada perlakuan vernalisasi 4 minggu yang tidak berbeda nyata dengan perlakuan vernalisasi 8 minggu, sedangkan ada pengamatan 4 dan 8 MST rerata jumlah daun terbaik diperoleh pada perlakuan vernalisasi 4 Minggu dengan jumlah daun lebih banyak (Tabel 2). Rerata panjang daun terbaik diperoleh pada perlakuan vernalisasi 4 Minggu pada pengamatan $1 \mathrm{MST}$, sedangkan pada pengamatan 4 MST dan 8 MST rerata panjang daun terbaik diperoleh pada perlakuan vernalisasi 8 minggu yang tidak berbeda nyata dengan perlakuan 4 minggu (Tabel 3). Rerata lebar daun terbaik pada pengamatan 2, 4 dan 8 MST diperoleh pada perlakuan vernalisasi 4 minggu yang tidak berbeda nyata dengan perlakuan vernalisasi 8 minggu (Tabel 4), sedangkan rerata tinggi tanaman terbaik terdapat pada perlakuan vernalisasi 8 minggu pada 2, 4 dan 8 MST (Tabel 5). Rerata diameter batang bawang putih pada pengamatan 4 dan 8 MST rerata tertinggi didapati pada perlakuan vernalisasi 4 minggu. Pengamatan hasil panen meliputi jumlah siung, berat basah, berat kering dan diamater umbi terbaik terdapat pada perlakuan 8 minggu yang tidak berbeda nyata dengan perlakuan 4 minggu. Rerata jumlah siung pada perlakuan 8 minggu lebih tinggi 75\% dibandingkan dengan tanpa vernalisasi, sedangkan rerata berat basah, berat kering dan diamater umbi pada perluan 8 minggu lebih tinggi masingmasing 32,7\% (berat basah), 69,9\% (berat kering) dan $50,67 \%$ (diamter umbi).

Hasil penelitian ini sesuai dengan hasil penelitian Jasmin (2013) dan Wu et al. (2015) yang menyatakan bahwa perlakuan vernalisasi dapat merangsang pertumbuhan tanaman terutama pertumbuhan pemanjangan tanaman melalui percepatan dormansi sehingga tanaman dapat tumbuh lebih cepat dengan normal. Percepatan pertumbuhan ini disebabkan karena adanya peningkatan aktivitas pembelahan sel dan giberelin endogen serta kandungan auksin (Jain, 2007; Dinarti et al., 2011). Pada percobaan yang dilakukan oleh Kim et al. (2003), melaporkan bahwa pada perlakuan vernalisasi dengan suhu $4{ }^{\circ} \mathrm{C}$ selama delapan minggu mampu mematahan dormansi umbi bibit bawang putih (Kim et al., 2003).

\section{B. Pengaruh Konsentrasi BAP (Benzil Amino Purin)}

Benzil Amino Purin termasuk dalam golongan sitokinin yang berperan dalam pertumbuhan tunas. Benzil Amino Purin merupakan salah satu jenis sitokinin yang tahan degradasi (Wattimena 1988; Mutmainah 2016). Selain itu BAP merupakan sitokinin sintetik yang paling aktif pada berbagai proses fisiologis tanaman seperti pembelahan sel, pembesaran sel, diferensiasi jaringan, dan perkembangan fase pembungaan (Amanullah et al. 2010). Hasil penelitian pemberian konsentrasi BAP pada tanaman bawang putih varietas Lumbu Hijau belum mampu memberikan pengaruh atau peningkatan terhadap semua variabel pertumbuhan dan 
perkembangan secara nyata. Hasil tersebut juga didukung oleh penelitian Rosniawaty et al. (2018), dimana pemberian BAP tidak berpengaruh nyata pada diamter batang tanaman teh. Hal tersebut diduga karena kandungan hormon endogen pada tanaman sudah dalam dalam kondisi optimal dalam memacu pertumbuhan tanaman dan peran dari sitokinin endogen hanya sebagai signal jarak jauh dalam mendukung pertumbuhan tanaman.

\section{Pengaruh interaksi antara lama vernalisasi dan konsentrasi BAP (Benzil Amino Purin)}

Hasil penelitian menunjukkan bahwa tidak terdapatnya interaksi antara lama vernalisasi dan konsentrasi BAP terhadap pertumbuhan dan perkembangan tanaman bawang putih varietas Lembu Hijau secara signifikansi. Hal tersebut diduga karena pengaruh dari faktor pelakuan secara mandiri yang lebih berpengaruh dibandingkan dengan interaksinya seperti yang yang dilaporkan oleh Steel dan Torrie (1991); Firgiyanto et al. (2019) bahwa bila interaksi tidak berbeda nyata maka faktor dari lama vernalisasi dan Konsentrasi BAP lebih berpengaruh secara mandiri.

Tabel 2. Rerata Jumlah Daun Pengaruh Lama Vernalisasi pada Beberapa Tingkat Umur

\begin{tabular}{lccc}
\hline \multirow{2}{*}{ Perlakuan } & \multicolumn{3}{c}{ Jumlah Daun (Helai) Umur ke- } \\
\cline { 2 - 4 } & $2 \mathrm{MST}$ & $4 \mathrm{MST}$ & $8 \mathrm{MST}$ \\
\hline V0 (Tanpa Vernalisasi) & $0 \mathrm{a}$ & $1,61 \mathrm{a}$ & $4,69 \mathrm{a}$ \\
V1 (Vernalisasi 2 Minggu) & $1,28 \mathrm{~b}$ & $3,04 \mathrm{~b}$ & $4,96 \mathrm{a}$ \\
V2 (Vernalisasi 4 Minggu) & $2,10 \mathrm{c}$ & $3,89 \mathrm{~d}$ & $6,98 \mathrm{~d}$ \\
V3 (Vernalisasi 6 Minggu) & $1,41 \mathrm{~b}$ & $3,07 \mathrm{~b}$ & $5,58 \mathrm{~b}$ \\
V4 (Vernalisasi 8 Minggu) & $2,02 \mathrm{c}$ & $3,65 \mathrm{c}$ & $6,41 \mathrm{c}$ \\
\hline
\end{tabular}

Keterangan: Rerata yang diikuti huruf yang sama terletak pada kolom yang sama menunjukkan tidak berbeda nyata pada DMRT $5 \%$ dan rerata yang diikuti huruf yang berbeda pada kolom yang sama menunjukkan berbeda nyata pada DMRT $5 \%$.

Tabel 3. Rerata Panjang Daun Pengaruh Lama Vernalisasi pada Beberapa Tingkat Umur

\begin{tabular}{lccc}
\hline \multirow{2}{*}{ Perlakuan } & \multicolumn{3}{c}{ Panjang Daun (cm) Umur ke- } \\
\cline { 2 - 5 } & $2 \mathrm{MST}$ & $4 \mathrm{MST}$ & $8 \mathrm{MST}$ \\
\hline V0 (Tanpa Vernalisasi) & $0 \mathrm{a}$ & $6,08 \mathrm{a}$ & $28,46 \mathrm{a}$ \\
V1 (Vernalisasi 2 Minggu) & $3,07 \mathrm{~b}$ & $18,56 \mathrm{~b}$ & $26,67 \mathrm{a}$ \\
V2 (Vernalisasi 4 Minggu) & $11,65 \mathrm{~d}$ & $26,49 \mathrm{c}$ & $33,08 \mathrm{~b}$ \\
V3 (Vernalisasi 6 Minggu) & $5,75 \mathrm{c}$ & $19,44 \mathrm{~b}$ & $29,22 \mathrm{a}$ \\
V4 (Vernalisasi 8 Minggu) & $13,11 \mathrm{~d}$ & $28,90 \mathrm{c}$ & $35,90 \mathrm{~b}$ \\
\hline
\end{tabular}

Keterangan: Rerata yang diikuti huruf yang sama terletak pada kolom yang sama menunjukkan tidak berbeda nyata pada DMRT $5 \%$ dan rerata yang diikuti huruf yang berbeda pada kolom yang sama menunjukkan berbeda nyata pada DMRT $5 \%$.

Tabel 4. Rerata Lebar Daun Pengaruh Lama Vernalisasi pada Beberapa Tingkat Umur

\begin{tabular}{|c|c|c|c|}
\hline \multirow{2}{*}{ Perlakuan } & \multicolumn{3}{|c|}{ Lebar Daun $(\mathrm{cm})$ Umur ke- } \\
\hline & $2 \mathrm{MST}$ & $4 \mathrm{MST}$ & $8 \mathrm{MST}$ \\
\hline V0 (Tanpa Vernalisasi) & $0 \mathrm{a}$ & $0,55 \mathrm{a}$ & $1,16 \mathrm{~b}$ \\
\hline V1 (Vernalisasi 2 Minggu) & $0,34 b$ & $0,86 b$ & $0,98 \mathrm{a}$ \\
\hline V2 (Vernalisasi 4 Minggu) & $0,80 \mathrm{c}$ & $1,20 \mathrm{~d}$ & $1,13 b$ \\
\hline V3 (Vernalisasi 6 Minggu) & $0,41 b$ & $0,81 b$ & $0,97 \mathrm{a}$ \\
\hline V4 (Vernalisasi 8 Minggu) & $0,82 \mathrm{c}$ & $1,03 \mathrm{c}$ & $1,04 \mathrm{ab}$ \\
\hline
\end{tabular}

Keterangan: Rerata yang diikuti huruf yang sama terletak pada kolom yang sama menunjukkan tidak berbeda nyata pada DMRT $5 \%$ dan rerata yang diikuti huruf yang berbeda pada kolom yang sama menunjukkan berbeda nyata pada DMRT $5 \%$. 
Tabel 5. Rerata Tinggi Tanaman Pengaruh Vernalisasi pada Beberapa Tingkat Umur

\begin{tabular}{|c|c|c|c|}
\hline \multirow{2}{*}{ Perlakuan } & \multicolumn{3}{|c|}{ Tinggi Tanaman $(\mathrm{cm})$ Umur ke- } \\
\hline & $2 \mathrm{MST}$ & $4 \mathrm{MST}$ & $8 \mathrm{MST}$ \\
\hline V0 (Tanpa Vernalisasi) & $0 \mathrm{a}$ & $7,48 \mathrm{a}$ & $31,64 a$ \\
\hline V1 (Vernalisasi 2 Minggu) & $4,36 \mathrm{ab}$ & $21,33 b$ & $29,81 \mathrm{a}$ \\
\hline V2 (Vernalisasi 4 Minggu) & $14,35 \mathrm{c}$ & $31,75 d$ & $39,07 \mathrm{c}$ \\
\hline V3 (Vernalisasi 6 Minggu) & $7,14 \mathrm{~b}$ & $24,19 \mathrm{c}$ & $34,92 b$ \\
\hline V4 (Vernalisasi 8 Minggu) & $19,25 d$ & $35,54 \mathrm{e}$ & $42,23 d$ \\
\hline
\end{tabular}

Keterangan: Rerata yang diikuti huruf yang sama terletak pada kolom yang sama menunjukkan tidak berbeda nyata pada DMRT $5 \%$ dan rerata yang diikuti huruf yang berbeda pada kolom yang sama menunjukkan berbeda nyata pada DMRT $5 \%$.

Tabel 6. Rerata Diameter Batang Pengaruh Lama Vernalisasi pada Beberapa Tingkat Umur

\begin{tabular}{lcc}
\hline \multirow{2}{*}{ Perlakuan } & \multicolumn{2}{c}{ Diameter Batang (cm) Umur ke- } \\
\cline { 2 - 3 } & $4 \mathrm{MST}$ & $6 \mathrm{MST}$ \\
\hline V0 (Tanpa Vernalisasi) & $0,49 \mathrm{a}$ & $3,29 \mathrm{~b}$ \\
V1 (Vernalisasi 2 Minggu) & $0,47 \mathrm{a}$ & $3,67 \mathrm{a}$ \\
V2 (Vernalisasi 4 Minggu) & $0,64 \mathrm{~b}$ & $5,65 \mathrm{~d}$ \\
V3 (Vernalisasi 6 Minggu) & $0,52 \mathrm{a}$ & $4,22 \mathrm{~b}$ \\
V4 (Vernalisasi 8 Minggu) & $0,62 \mathrm{~b}$ & $4,97 \mathrm{c}$ \\
\hline
\end{tabular}

Keterangan: Rerata yang diikuti huruf yang sama terletak pada kolom yang sama menunjukkan tidak berbeda nyata pada DMRT $5 \%$ dan rerata yang diikuti huruf yang berbeda pada kolom yang sama menunjukkan berbeda nyata pada DMRT $5 \%$.

Tabel 7. Rerata Jumlah Siung, Berat Basah, Berat Kering dan Diameter Umbi Pengaruh Lama Vernalisasi pada Beberapa Tingkat Umur

\begin{tabular}{ccccc}
\hline \multirow{2}{*}{ Perlakuan } & \multicolumn{4}{c}{ Hasil Panen } \\
\cline { 2 - 5 } & $\begin{array}{c}\text { Jumlah Siung } \\
\text { (buah) }\end{array}$ & $\begin{array}{c}\text { Berat Basah } \\
(\mathrm{gr})\end{array}$ & $\begin{array}{c}\text { Berat Kering } \\
(\mathrm{gr})\end{array}$ & $\begin{array}{c}\text { Diameter } \\
\text { Umbi }(\mathrm{mm})\end{array}$ \\
\hline (Tanpa Vernalisasi) & $1,53 \mathrm{a}$ & $4,08 \mathrm{~b}$ & $1,52 \mathrm{a}$ & $12,11 \mathrm{a}$ \\
V1 (Vernalisasi 2 Minggu) & $3,38 \mathrm{~b}$ & $3,49 \mathrm{a}$ & $1,67 \mathrm{a}$ & $17,88 \mathrm{~b}$ \\
V2 (Vernalisasi 4 Minggu) & $5,11 \mathrm{c}$ & $5,57 \mathrm{c}$ & $4,26 \mathrm{bc}$ & $23,59 \mathrm{c}$ \\
V3 (Vernalisasi 6 Minggu) & $5,08 \mathrm{c}$ & $4,98 \mathrm{bc}$ & $4,16 \mathrm{~b}$ & $22,38 \mathrm{c}$ \\
V4 (Vernalisasi 8 Minggu) & $6,13 \mathrm{~d}$ & $6,06 \mathrm{c}$ & $5,06 \mathrm{c}$ & $24,55 \mathrm{c}$ \\
\hline
\end{tabular}

Keterangan: Rerata yang diikuti huruf yang sama terletak pada kolom yang sama menunjukkan tidak berbeda nyata pada DMRT $5 \%$ dan rerata yang diikuti huruf yang berbeda pada kolom yang sama menunjukkan berbeda nyata pada DMRT $5 \%$.

\section{KESIMPULAN}

1. Pemberian perlakuan lama vernalisasi berpengaruh nyata terhadap pertumbuhan jumlah daun, panjang daun, lebar daun, tinggi tanaman, diameter batang, jumlah siung, berat basah, berat kering, dan diameter umbi, akan tetapi tidak berpengaruh nyata pada lebar daun 6 MST. Lama vernalisasi terbaik dalam meningkatkan pertumbuhan dan produksi bawanag putih diperoleh pada perlakuan 4 minggu dan 8 minggu.

2. Pemberian perlakuan konsentrasi BAP (Benzil Amino Purin) serta interaksinya dengan lama vernalisasi masih belum mampu meningkatkan pertumbuhan dan perkembangan bawang putih varietas Lumbu Hijau.

\section{DAFTAR PUSTAKA}

Amanullah M.M., S. Sekar, S. Vincent. 2010. Plant growth substances in crop production: "A review". Asian J. Plant Sci. 9: 215-22.

Badan Pusat Statistik (BPS). 2017. Statistik Indonesia 2017. Jakarta: Badan Pusat Statistika. No. Katalog: 1101001. ISSN: 0126-2912. Diakses di https://www.bps.go.id /websitelpdf_publikasi/Statistik-Indonesia-2017.pdf. [23 juli 2018]

Dinarti, D., B.S. Purwoko, A. Purwito, A.D. Susila. 2011. Perbanyakan tunas mikro pada beberapa umur simpan umbi dan pembentukan umbi mikro bawang merah pada dua suhu ruang kultur. J. Agron. Indonesia 39: 97-102. 
Direktorat Jendral Hortikultura. 2017. Pengembangan Bawang Putih. Kementrian Pertanian. Jakarta.

FAO Statistics. 2014. Indonesia Garlic Produkction. Statistics. 2014. Diakses di http://www.faostat.org. [23 juli 2018]

Firgiyanto, R., T. Harjoso, E.W. Tini. 2019. Kajian pertumbuhan bibit belimbing pada pemberian beberapa dosis pupuk majemuk NPK dan pupuk daun. Agrivigor 11(2): 88-95

Jain R., A.K. Shrivastava, S. Solomon, R.L. Yadav. 2007. Low temperature stress - induced biochemical changes affect stubble bud sprouting in sugarcane (Saccharum spp. hybrid). Plant Growth Regul. 53:1723.

Jasmi, S. Endang, I. Didik. 2013. Pengaruh vernalisasi umbi terhadap pertumbuhan, hasil, dan pembungaan bawang merah (Allium Cepa L. Aggregatum Group) di dataran rendah. Ilmu Pertanian 16 (1): 42 - 57.

Kementrian Pertanian. 2016. Konsumsi bawang merah 2002-20017. Diakses Di https://lokadata.beritagar.id. [23 juli 2018]

Kim E.K., E.J. Hahn, H.N. Murthy, K.Y. Paek. 2003. High frequency of shoot multiplication and bulblet formation of garlic in liquid cultures. Plant Cell Tiss. Org. Cult. 73:231236.
Mutmainah S, 2016. Induksi tunas adventif bawang putih tunggal (Allium Sativum) dengan penambahan BAP dan NAA secara in vitro. Skripsi. Universitas Islam Negeri Maulana Malik Ibrahim Malang, Malang (tidak dipublikasikan).

Randi. 2015. Pengaruh kombinasi media terhadap pertumbuhan tunas bulbil bawang putih (Allium sativum L.). Skripsi. Fakultas Pertanian, Bogor (tidak dipublikasikan).

Rosliani R., E.R. Palupi, Y. Hilman. 2012. Penggunaan benzil amino purine (BAP) dan boron untuk meningkatkan produksi dan mutu benih TSS bawang merah (Allium cepa var. ascalonicum) di dataran tinggi. J. Hort 22 (3): 242-50.

Steel R.G.D., J.H. Torrie. 1991. Prinsip dan Prosedur Statistika Suatu Pendekatan Biometrik. PT Gramedia. Jakarta

Rosniawaty S., I.R.D. Anjasari, R. Sudirja. 2018. Aplikasi sitokinin untuk meningkatkan pertumbuhan tanaman teh didataran rendah. J. TIDP 5(1): 31-38.

Wattimena. 1988. Zat Pengatur Tumbuh Tanaman. Institut Pertanian Bogor. Bogor.

Wu, C., M. Wang, Y. Dong, H. Meng. 2015 Growth, bolting and yield of garlic (Allium sativum L.) in response to clove chilling 